\title{
SCIDoC
}

\author{
International Journal of Dentistry and Oral Science (IJDOS) \\ ISSN: 2377-8075
}

\section{Endodontic Management Of Aberrant Root Canal Anatomy In Mandibular Premolars}

Research Article

Pradeep Solete ${ }^{1 *}$, Sneha Pai ${ }^{2}$

${ }^{1}$ Associate Professor, Department of Conservative Dentistry and Endodontics, Saveetha Dental College and Hospitals, Saveetha Institute of Medical and Technical Sciences, Saveetha University 162, Poonamallee High Road, Chennai 600077, Tamilnadu, India.

${ }^{2}$ Department of Conservative Dentistry \& Endodontics, Saveetha Dental College and Hospitals, Saveetha Institute of Medical and Technical Sciences, Saveetha University, Chennai, India.

\section{Abstract}

For the success of endodontic treatment, an understanding of root canal anatomy and morphology is very important. Proper endodontic management would require a thorough debridement, disinfection and obturation of the root canal. Mandibular premolars are termed as "enigma to endodontists" as they are believed to possess aberrant root canal anatomies such as multiple root canals, apical deltas and lateral canals. Such aberrant anatomies depend on various factors like ethnic background, age and gender of the population. These variations in anatomies can be identified using various radiographic techniques and under magnification. Failure to identify and disinfect additional canals would result in flare ups and failures.

This article reports the aberrant mandibular premolar anatomies and discusses the treatment recommendations for a successful endodontic outcome.

Keywords: Mandibular Premolar; Vertucci’s Classification; CBCT; Aberrant Canal Anatomy; Periapical Radiography.

\section{Introduction}

Knowledge of root canal anatomy along with radiographic details and magnification are very important for the successful endodontic management of teeth with aberrant root canal anatomies which in turn would determine the prognosis of the treated tooth $[1,2]$. Inability to locate, disinfect and obturate any of the roots or root canals would result in treatment failure [3, 4]. Mandibular premolars have been reported to be the most challenging teeth for endodontic management, especially when they are present with multiple roots or canals $[5,6]$. The likelihood to possess variations, narrow mesio distal dimensions, practice of conservative accesses, apical bifurcations and trifurcations of the canal and compromised visibility add on to the difficulty of endodontically managing these teeth [2].

Endodontic treatment aims to debride and disinfect the root canal so as to prepare it to receive an inert filling material that will block all portals of exit [7-9]. Failure to disinfect or obturate root canals would result in treatment failure $[10,11]$. Mandibular premolars are believed to possess complex root canal anatomies with most of the teeth showing Vertucci's Type I canal configuration and about $20 \%$ of the teeth showing prevalence of multiple canals.

Previously our team has a rich experience in working on various research projects across multiple disciplines [12-26]. Now the growing trend in this area motivated us to pursue this project. This case report discusses endodontic management of a mandibular 1 st and 2 nd premolar with varied root canal anatomy.

\section{Case Report 1}

\section{Mandibular First Premolar (44) With Two Roots and Two Canals}

A 45 year old female patient reported with pain in 44 which ag-

\section{*Corresponding Author}

Pradeep Solete,

Associate Professor, Department of Conservative Dentistry and Endodontics, Saveetha Dental College and Hospitals, Saveetha Institute of Medical and Technical Sciences, Saveetha University 162, Poonamallee High Road, Chennai 600077, Tamilnadu, India.

Tel: +919710404482

Email Id: pradeeps@saveetha.com

Received: May 03, 2021

Accepted: May 26, 2021

Published: May 30, 2021

Citation: Pradeep Solete, Sneha Pai. Endodontic Management Of Aberrant Root Canal Anatomy In Mandibular Premolars. Int J Dentistry Oral Sci. 2021;08(05):2601-2604. doi: http://dx.doi.org/10.19070/2377-8075-21000509

Copyright: Pradeep Solete ${ }^{\circ}$ 2021. This is an open-access article distributed under the terms of the Creative Commons Attribution License, which permits unrestricted use, distribution and reproduction in any medium, provided the original author and source are credited. 
gravated on chewing and having cold beverages. Patient gave a history of initiated root canal therapy 3 months ago. Clinical examination showed a prepared access cavity in 44 with tenderness to percussion. Radiographic examination revealed radiolucency in the coronal portion that was confluent with the root canals, indicative of initiated root canal treatment in 44 along with periapical radiolucency. Angled radiograph (SLOB technique) showed the presence of 2 roots in 44 . The case was diagnosed as previously initiated root canal treatment in 44 with symptomatic apical periodontitis.

\section{Treatment Protocol}

Patient was informed about the treatment protocol and an informed consent was taken. The tooth was anesthetized using an inferior alveolar nerve block with 2\% Lignocaine HCL containing 1:2 lacs units of adrenaline (Lignox, Indoco Remedies Ltd, India). Access cavity was modified with Endo-Z bur (Dentsply-Sirona, USA). Magnification was achieved using an OPMI pico dental operating microscope (CarlZeiss, Germany). Since the radiograph showed bifurcation of the root in the middle third, the access cavity was flared for easy access and visibility. The canals were negotiated using a size $10 \mathrm{~K}$ file (Dentsply-Sirona, USA). Cleaning and shaping was done using ProTaper Gold rotary files (DentsplySirona, USA) with the crown down technique using 3\% sodium hypochlorite and 17\% EDTA which was activated using Endoactivator (Dentsply-Sirona, USA). The root canals were obturated using cold lateral condensation technique using resin sealer $(\mathrm{AH}$ plus, Dentsply-Sirona, USA). Post obturation radiograph was taken to assess the quality of obturation following which a permanent restoration was placed. (Figure 1).

\section{Case Report 2}

\section{Mandibular Second Premolar (45) With Two Roots and Four Canals}

A 59 year old male patient reported with pain in 45 which aggravated on having cold beverages and on chewing. Patient gave a history of initiated root canal treatment 1 week ago. Clinical examination showed deep cervical abrasion and recession on the buccal aspect of 45 with a temporary restoration. Radiograph revealed radiolucency in the coronal aspect of 45 that was confluent with the root canal indicative of initiated root canal treatment along with widened periodontal ligament space. It was diagnosed as previously initiated root canal treatment in 45 with symptomatic apical periodontitis.

CBCT scan was taken to evaluate the canal morphology.

\section{Treatment Protocol}

The same treatment protocol was followed as mentioned above. In this case, the mandibular premolar was seen to have two roots that had two root canals which split apically to exit as four canals. All the canals were negotiated, disinfected, shaped and obturated. (Figure 2).

\section{Discussion}

Mandibular premolars show complex and highly variable root ca-

Figure 1. Mandibular first premolar (44) a. Pre operative radiograph. b. Pre operative CBCT. c. Working length determination radiograph. d. Obturation radiograph.

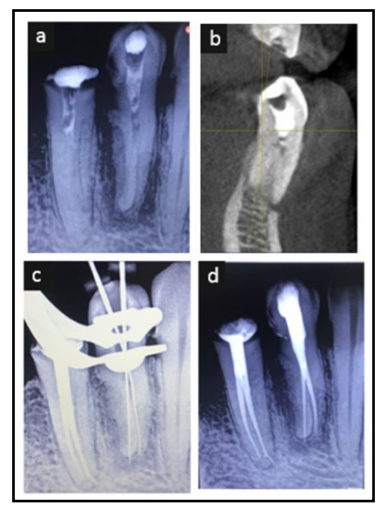

Figure 2. Mandibular second premolar (45) a. Pre operative radiograph. b. Pre operative CBCT. c. Working length determination radiograph. d. Obturation radiograph.

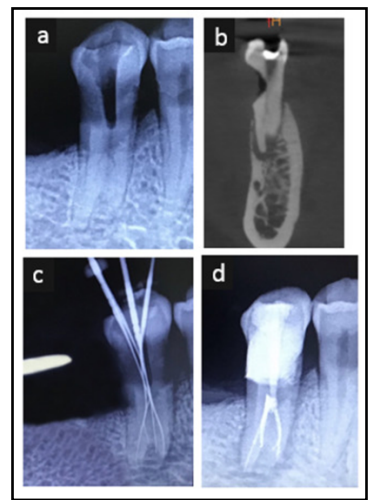


nal anatomy which makes endodontic treatment very challenging. Multiple root canals have been identified in mandibular premolars with the incidence of more canals in black populations [27, 28].

The first step in root canal treatment would be to predict the root canal anatomy. This could be made possible by tracing the anatomical landmarks on the pulp floor which would disclose supplementary canals if present [29]. Tactile exploration of the pulpal floor carefully with hand files is recommended rather than searching for the canals at random places.

Further identification of aberrant anatomy is made possible with the help of angled radiographs, which on careful observation would show the presence of multiple roots or canals [27, 29]. Careful observation of the root shape and its position relative to the tooth would also help in identifying multiple canals [30]. Also, canal continuity should be looked for. Sudden disappearance of a canal would indicate towards a splitting canal.

If multiple canals are suspected and not clearly identified with conventional radiographs, CBCT imaging can also be used as the presence of additional canals or splitting of canals would be clearly evident in different sections of the scan $[31,32]$.

Endodontic management of premolars with multiple root canals can be successfully done by complete removal of pulp tissue from the root canal system which is achieved by careful exploration of the canal system with tactile sensation or magnification, thorough disinfection of the root canal with activation followed by three dimensional obturation to seal the canal space. Application of knowledge regarding root canal anatomies supplemented with appropriate diagnostic aids would help in achieving successful outcome in the management of cases with aberrant anatomies.

Our institution is passionate about high quality evidence based research and has excelled in various fields [16, 33-43].

\section{Clinical Significance}

The cases of aberrant anatomies described above have been successfully managed endodontically mainly with the aid diagnostic aids that helped in predicting the canal anatomy and magnification which helped in the visualization of the canals. Also a rare variation of aberrant anatomy (mandibular premolar with four canals) has been observed and managed in the case report. This article highlights the importance of acquiring knowledge on root canal anatomy along with disinfection and sealing of the root canal space in achieving predictable outcomes after root canal treatment.

\section{References}

[1]. Low JF, Dom TNM, Baharin SA. Magnification in endodontics: A review of its application and acceptance among dental practitioners. Eur J Dent. 2018 Oct-Dec;12(4):610-616. Pubmed PMID: 30369811

[2]. Albuquerque D, Kottoor J, Hammo M. Endodontic and clinical considerations in the management of variable anatomy in mandibular premolars: a literature review. Biomed Res Int. 2014;2014:512574. Pubmed PMID: 24895584

[3]. Rödig T, Hülsmann M. Diagnosis and root canal treatment of a mandibular second premolar with three root canals. Int Endod J. 2003 Dec;36(12):9129. Pubmed PMID: 14689961.

[4]. Cantatore G, Berutti E, Castellucci A. Missed anatomy: frequency and clini- cal impact. Endodontic Topics. 2006 Nov;15(1):3-1.

[5]. Sert S, Bayirli GS. Evaluation of the root canal configurations of the mandibular and maxillary permanent teeth by gender in the Turkish population. J Endod. 2004 Jun;30(6):391-8. Pubmed PMID: 15167464.

[6]. Slowey RR. Root canal anatomy. Road map to successful endodontics. Dent Clin North Am. 1979 Oct;23(4):555-73. Pubmed PMID: 294389.

[7]. Zillich R, Dowson J. Root canal morphology of mandibular first and second premolars. Oral Surg Oral Med Oral Pathol. 1973 Nov;36(5):738-44. Pubmed PMID: 4518037.

[8]. INGLE JI. A standardized endodontic technique utilizing newly designed instruments and filling materials. Oral Surg Oral Med Oral Pathol. 1961 Jan;14:83-91. Pubmed PMID: 13717698.

[9]. Weller RN, Kimbrough WF, Anderson RW. A comparison of thermoplastic obturation techniques: adaptation to the canal walls. J Endod. 1997 Nov;23(11):703-6. Pubmed PMID: 9587313.

[10]. Wolcott J, Ishley D, Kennedy W, Johnson S, Minnich S, Meyers J. A 5 yr clinical investigation of second mesiobuccal canals in endodontically treated and retreated maxillary molars. J Endod. 2005 Apr;31(4):262-4. Pubmed PMID: 15793380.

[11]. Hoen MM, Pink FE. Contemporary endodontic retreatments: an analysis based on clinical treatment findings. J Endod. 2002 Dec;28(12):834-6. Pubmed PMID: 12489654.

[12]. Govindaraju L, Gurunathan D. Effectiveness of Chewable Tooth Brush in Children-A Prospective Clinical Study. J Clin Diagn Res. 2017 Mar;11(3):ZC31-ZC34. Pubmed PMID: 28511505.

[13]. Christabel A, Anantanarayanan P, Subash P, Soh CL, Ramanathan M, Muthusekhar MR, et al. Comparison of pterygomaxillary dysjunction with tuberosity separation in isolated Le Fort I osteotomies: a prospective, multi-centre, triple-blind, randomized controlled trial. Int J Oral Maxillofac Surg. 2016 Feb;45(2):180-5. Pubmed PMID: 26338075.

[14]. Soh CL, Narayanan V. Quality of life assessment in patients with dentofacial deformity undergoing orthognathic surgery--a systematic review. Int J Oral Maxillofac Surg. 2013 Aug;42(8):974-80. Pubmed PMID: 23702370.

[15]. Mehta M, Deeksha, Tewari D, Gupta G, Awasthi R, Singh H, et al. Oligonucleotide therapy: An emerging focus area for drug delivery in chronic inflammatory respiratory diseases. Chem Biol Interact. 2019 Aug 1;308:206215. Pubmed PMID: 31136735.

[16]. Ezhilarasan D, Apoorva VS, Ashok Vardhan N. Syzygium cumini extract induced reactive oxygen species-mediated apoptosis in human oral squamous carcinoma cells. J Oral Pathol Med. 2019 Feb;48(2):115-121. Pubmed PMID: 30451321.

[17]. Campeau PM, Kasperaviciute D, Lu JT, Burrage LC, Kim C, Hori M, et al. The genetic basis of DOORS syndrome: an exome-sequencing study. Lancet Neurol. 2014 Jan;13(1):44-58. Pubmed PMID: 24291220.

[18]. Sneha S. Knowledge and awareness regarding antibiotic prophylaxis for infective endocarditis among undergraduate dental students. Asian Journal of Pharmaceutical and Clinical Research. 2016 Oct 1:154-9.

[19]. hristabel SL, Gurunathan D. Prevalence of type of frenal attachment and morphology of frenum in children, Chennai, Tamil Nadu. World J Dent. 2015 Oct;6(4):203-7.

[20]. Kumar S, Rahman RE. Knowledge, awareness, and practices regarding biomedical waste management among undergraduate dental students. Asian Journal of Pharmaceutical and Clinical Research. 2017;10(8):341.

[21]. Sridharan G, Ramani P, Patankar S. Serum metabolomics in oral leukoplakia and oral squamous cell carcinoma. J Cancer Res Ther. 2017 JulSep;13(3):556-561. Pubmed PMID: 28862226.

[22]. Ramesh A, Varghese SS, Doraiswamy JN, Malaiappan S. Herbs as an antioxidant arsenal for periodontal diseases. J Intercult Ethnopharmacol. 2016 Jan 27;5(1):92-6. Pubmed PMID: 27069730.

[23]. Thamaraiselvan M, Elavarasu S, Thangakumaran S, Gadagi JS, Arthie T. Comparative clinical evaluation of coronally advanced flap with or without platelet rich fibrin membrane in the treatment of isolated gingival recession. J Indian Soc Periodontol. 2015 Jan-Feb;19(1):66-71. Pubmed PMID: 25810596.

[24]. Thangaraj SV, Shyamsundar V, Krishnamurthy A, Ramani P, Ganesan K, Muthuswami M, et al. Molecular Portrait of Oral Tongue Squamous Cell Carcinoma Shown by Integrative Meta-Analysis of Expression Profiles with Validations. PLoS One. 2016 Jun 9;11(6):e0156582. Pubmed PMID: 27280700.

[25]. Ponnulakshmi R, Shyamaladevi B, Vijayalakshmi P, Selvaraj J. In silico and in vivo analysis to identify the antidiabetic activity of beta sitosterol in adipose tissue of high fat diet and sucrose induced type- 2 diabetic experimental rats. Toxicol Mech Methods. 2019 May;29(4):276-290. Pubmed PMID: 30461321.

[26]. Ramakrishnan M, Bhurki M. Fluoride, Fluoridated Toothpaste Efficacy And Its Safety In Children-Review. International Journal of Pharmaceutical Research. 2018 Oct 1;10(04):109-14. 
[27]. Trope M, Elfenbein L, Tronstad L. Mandibular premolars with more than one root canal in different race groups. J Endod. 1986 Aug;12(8):343-5. Pubmed PMID: 3462297.

[28]. Chopra P, Bal CS. Study of root canals and their configuration in buccal roots of maxillary first permanent molar. Indian J Dent Res. 1989 JanMar;1(1):3-14. Pubmed PMID: 2490119.

[29]. De Moor RJ, Calberson FL. Root canal treatment in a mandibular second premolar with three root canals. J Endod. 2005 Apr;31(4):310-3. Pubmed PMID: 15793392.

[30]. Mittal S, Kumar T, Mittal S, Sharma J. Mandibular premolars with aberrant canal morphology: An endodontic challenge. J Conserv Dent. 2014 Sep;17(5):491-4. Pubmed PMID: 25298656.

[31]. Slowey RR. Radiographic aids in the detection of extra root canals. Oral Surg Oral Med Oral Pathol. 1974 May;37(5):762-72. Pubmed PMID: 4524384.

[32]. Patel S, Brown J, Pimentel T, Kelly RD, Abella F, Durack C. Cone beam computed tomography in Endodontics - a review of the literature. Int Endod J. 2019 Aug;52(8):1138-1152. Pubmed PMID: 30868610.

[33]. Vijayashree Priyadharsini J. In silico validation of the non-antibiotic drugs acetaminophen and ibuprofen as antibacterial agents against red complex pathogens. J Periodontol. 2019 Dec;90(12):1441-1448. Pubmed PMID: 31257588

[34]. J PC, Marimuthu T, C K, Devadoss P, Kumar SM. Prevalence and measurement of anterior loop of the mandibular canal using CBCT: A cross sectional study. Clin Implant Dent Relat Res. 2018 Aug;20(4):531-534. Pubmed PMID: 29624863.

[35]. Ramesh A, Varghese S, Jayakumar ND, Malaiappan S. Comparative estimation of sulfiredoxin levels between chronic periodontitis and healthy patients - A case-control study. J Periodontol. 2018 Oct;89(10):1241-1248. Pubmed PMID: 30044495.

[36]. Ramadurai N, Gurunathan D, Samuel AV, Subramanian E, Rodrigues SJL. Effectiveness of $2 \%$ Articaine as an anesthetic agent in children: randomized controlled trial. Clin Oral Investig. 2019 Sep;23(9):3543-3550. Pubmed PMID: 30552590.
[37]. Sridharan G, Ramani P, Patankar S, Vijayaraghavan R. Evaluation of salivary metabolomics in oral leukoplakia and oral squamous cell carcinoma. J Oral Pathol Med. 2019 Apr;48(4):299-306. Pubmed PMID: 30714209.

[38]. Mathew MG, Samuel SR, Soni AJ, Roopa KB. Evaluation of adhesion of Streptococcus mutans, plaque accumulation on zirconia and stainless steel crowns, and surrounding gingival inflammation in primary molars: randomized controlled trial. Clin Oral Investig. 2020 Sep;24(9):3275-3280. Pubmed PMID: 31955271.

[39]. Samuel SR. Can 5-year-olds sensibly self-report the impact of developmental enamel defects on their quality of life? Int J Paediatr Dent. 2021 Mar;31(2):285-286. Pubmed PMID: 32416620.

[40]. R H, Ramani P, Ramanathan A, R JM, S G, Ramasubramanian A, et al. CYP2 C9 polymorphism among patients with oral squamous cell carcinoma and its role in altering the metabolism of benzo[a]pyrene. Oral Surg Oral Med Oral Pathol Oral Radiol. 2020 Sep;130(3):306-312. Pubmed PMID: 32773350 .

[41]. Chandrasekar R, Chandrasekhar S, Sundari KKS, Ravi P. Development and validation of a formula for objective assessment of cervical vertebral bone age. Prog Orthod. 2020 Oct 12;21(1):38. Pubmed PMID: 33043408.

[42]. Vijayashree Priyadharsini J, Smiline Girija AS, Paramasivam A. In silico analysis of virulence genes in an emerging dental pathogen A. baumannii and related species. Arch Oral Biol. 2018 Oct;94:93-98. Pubmed PMID: 30015217.

[43]. Ezhilarasan D, Apoorva VS, Ashok Vardhan N. Syzygium cumini extract induced reactive oxygen species-mediated apoptosis in human oral squamous carcinoma cells. J Oral Pathol Med. 2019 Feb;48(2):115-121. Pubmed PMID: 30451321. 